\title{
Medineli Kadın Sahâbe ve Tâbiûnun Tefsire Katkıları
}

\author{
Ceyda Gürman \\ Dr. Arş. Gör., Sinop Üniversitesi (ROR ID: 004ah3r71) \\ İlahiyat Fakültesi, Tefsir Anabilim Dalı \\ Ph.D. Research Assistant, Sinop University, Faculty of Teology, Department of Tafsir \\ Sinop/Turkey \\ cey827@gmail.com \\ ORCID: 0000-0002-4136-9766
}

\begin{abstract}
The efforts of the șahāaba, who constitute the most important circle in the tafsīr and of the tābi ūn (successors of șahāba) who grew up in their hands to understand the Qur'ān, took their place in the studies on the history of tafsir. However, it is seen in the researches conducted on the first century of hijrī that certain names are emphasized, and especially the women șahāba and tābitūn are seems to be undervalued and not noted attention. However, with the construction of the Masjid an-Nabawī after the hijra, The Prophet Muhammad (pbuh) encouraged women to participate in mosques through various occasions for the purpose of worshiping and knowledge, and made them aware of the verses of the Qur'ān. Such practices were continued during the sahāba and tābi ūn period and women gained the basis of sciences such as qirā'a, hadìth, fiqh and tafsīr that would be formed in the future. Medina, where a vibrant scientific life shaped around the Masjid an-Nabawī was lived, offered opportunities for women to participate in this scientific vitality. Hafșa bt 'Umar (d. 45/665) and Umm Salama (d. 62/681), especially 'Â' 'isha (d. 58/678), one of the ladies of the Prophet (pbuh), played an important role in the education of women. Apart from the wives of The Prophet (pbuh), there are many other women șahāba who have knowledge such as alShifā bt. 'Abd Allāh (d. 20/641 around), Umm Waraqā bt. 'Abd Allāh b. Ḥārith (before d. 23/644), Asmā’ bt. Yazīd (d. 30/650), Asmā’ bt. Abī Bakr al-Siddīq (d. 73/692) and Samrā bt. Nuhayk (d.?) in Medina. Outstanding among scholars of the period of tābitūn, who acquired most of her science from 'Ā'isha, 'Amra bt. 'Abd al-Rahmān (d.106 / 724), has been emphasized. In addition to the narrations reflected in the tafsir sources, many famous scholars have received knowledge from her, reveals that it is among the important names of Medina. Other than 'Amra, the names Umm
\end{abstract}

\footnotetext{
Bu makale, Yalova Üniversitesi Sosyal Bilimler Enstitüsü’nde tamamlanan “Tâbiûn Dönemi Tefsiri ve Medineli Müfessirler" adlı doktora tezimizin ilgili başlıklarından istifade edilerek hazırlanmıştır./This article has been prepared by benefiting from the related titles of my doctoral thesis named "Tafsīr of Tābitūn Period and Medina Mufassirs" completed in Yalova University Institute of Social Sciences.

Intihal Taraması/Plagiarism Detection: Bu makale intihal taramasından geçirildi/This paper was checked for plagiarism Etik Beyan/Ethical Statement: Bu çalışmanın hazırlanma sürecinde bilimsel ve etik ilkelere uyulduğu ve yararlanılan tüm çalışmaların kaynakçada belirtildiği beyan olunur/It is declared that scientific and ethical principles have been followed while carrying out and writing this study and that all the sources used have been properly cited (Ceyda Gürman).

Geliş/Received: 03 Ocak/January 2021 | Kabul/Accepted: 07 Mart/March 2021 | Yayın/Published: 20 Mart/March 2021 Atıf/Cite as: Ceyda Gürman, "Medineli Kadın Sahâbe ve Tâbiûnun Tefsire Katkıları = Contributions to Tafsīr of the female Șahāābe and Tābi'ūn from Medina”, Eskiyeni 43 (Mart/March 2021), 77-93. https://doi.org/10.37697/eskiyeni.853094 CC BY-NC 4.0 | This paper is licensed under a Creative Commons Attribution-NonCommercial License
} 
Kulthūm bt. Abī Bakr al-Siddīq (after d. 58/678); Zaynab bt. 'Alī b. Abī Ṭālib (d. 62/682); Ḥafṣa bt. 'Abd al-Rahmān b. Abī Bakr al-Ṣiddīq (d. 80/699 around), Șafiyya bt. Abī 'Ubayd (d. 90/709 around), 'Ā'isha bt. Ṭalha b. 'Ubayd Allāh (d. 101/719), 'Ā'isha bt. Șa'd b. Abī Waqqās (d. 117/735) and Fāțima bt. al-Mundhir b. Zubayr b. al-'Awwām (48/668- d. ?) can be mentioned. In this study, the scholar women from șahāba and tābitūn were touched, the narrations recorded in tafsīr sources were examined and the results to be attained from the information obtained were discussed. In the determination of the names, țabaqāt and terācìm type works were used, for the interpretation of the tafsīr, 'ulūm al-Qur'ān and hadīth sources were used as well as the tafsīr sources. As a result of the readings made, it has been observed that the information given about women șahāba and tābi'un in these sources is highly limited. Similarly, there is no reference to their position in the science of tafsir. One of the limitations of our research is the minority of commentaries and narrations coming from them numerically. This situation was evaluated considering the socio-cultural structure of the period and 'Amra, who was accepted as the transmitter of 'A''isha's knowledge, compared to another student of 'Urwa b. al-Zubayr (d. 94/713) the situations such as recording much less of his narrations have been criticized. In today's studies, it is aimed to reach a general opinion about the place of women in education and their contribution to tafsir in Medina in the first century, based on the fact that the place of early women in scientific life has not been mentioned sufficiently.

\section{Keywords}

Tafsīr, Medina, Șahāba, Tābitūn, Woman

\section{Medineli Kadın Sahâbe ve Tâbiûnun Tefsire Katkıları}

\section{Öz}

Tefsirde en önemli halkayı oluşturan sahâbîlerin ve onların elinde yetişen tâbiîlerin Kur'ân'ı anlamaya yönelik büyük gayretleri tefsir tarihine dair çalışmalarda hak ettiği yeri almıştır. Bununla birlikte hicri ilk asra dair araştırmalarda, belirli isimler üzerinde durulduğu özellikle kadın sahâbe ve tâbiîlere yeterli ölçüde dikkat çekilmediği görülmektedir. Hâlbuki hicretten sonra Mescid-i Nebevî̀nin inşasıyla birlikte, Hz. Peygamber kadınların ibadet ve ilim maksadıyla mescitlere katılımlarını teşvik etmiş ve çeşitli vesilelerle onların da nâzil olmava devam eden Kur'ân âvetlerinden haberdar olmalarını sağlamıștır. Bu tür uvgulamalar sahâbe ve tâbiûn döneminde de sürdürülmüs kadınlar kıraat, hadis, fikıh ve tefsir gibi geleceğin ilimlerine temel teşkil edecek bilgilere vakıf olmuşlardır. Mescid-i Nebevî etrafında şekillenen canlı bir ilmî hayatın yaşandığı Medine, kadınların da bu ilmî canlılığa katılımı için imkânlar sunmuştur. Başta Hz. Peygamber hanımlarından Hz. Âişe bint Ebû Bekr es-Sıddık (öl. 58/678) olmak üzere Hz. Hafsa bint Ömer b. Hattâb (öl. 45/665) ve Hz. Ümmü Seleme (öl. 62/681) kadınların eğitiminde önemli roller üstlenmişlerdir. Medine'de Hz. Peygamber hanımları haricinde Şifâ bint Abdullah (öl. 20/641 civarı), Ümmü Varaka bint Abdullah b. Hâris (öl. 23/644'ten önce), Esmâ bint Yezîd (öl. 30/650), Esmâ bint Ebû Bekr es-Siddîk (öl. 73/692) ve Semra bint Nüheyk (öl. ?) gibi ilim sahibi birçok kadın sahâbe daha bulunmaktadır. Tâbiûn dönemi âlimleri arasında ise ilminin büyük kısmını Hz. Âişe'den edinen Amre bint Abdurrahmân (öl. 106/724) ön plana çıkmaktadır. Tefsir kaynaklarına yansıyan rivayetlerinin yanı sıra çok sayıda meşhur ulemanın kendisinden ilim alması, Medine'nin önemli isimleri arasında olduğunu göstermektedir. Amre haricinde Ümmü Külsûm bint Ebû Bekr (öl. 58/678'den sonra); Zeyneb bint Ali b. Ebû Tâlib (öl. 62/682); Hafsa bint Abdurrahman b. Ebû Bekr es-Sıddîk (öl. 80/699 civarı), Safiyye bint Ebû Ubeyd (öl. 90/709 civarı), Aişe bint Talha b. Ubeydullah (öl. 101/719), Âişe bint Sa'd b. Ebû Wakkās (öl. 117/735) ve Fâtıma bint el-Münzir b. Zübeyr b. Avvâm'ın (d. 48/668- öl. ?) isimleri sayılabilir. Sahâbe ve tâbiûndan Medineli âlim kadınlara temas ettiğimiz bu çalışmada, onların tefsir kaynaklarında kaydedilen rivayetlerinin çoğunluğu incelenmiş ve elde edilen sonuçlar tartı- 
şılmıştır. İsimlerin tesbitinde tabakāt ve terâcim türü eserlerden istifade edilmiş, tefsir yorumları için, tefsir kaynaklarının yanı sıra ulûmü'l-Kur'ân ve hadis kaynaklarına da başvurulmuştur. Yapılan okumalar neticesinde bu kaynaklarda, kadın sahâbî ve tâbiîler hakkında verilen bilgilerin son derece sınırlı olduğu görülmüştür. Benzer şekilde onların tefsir ilmindeki konumlarına dair bir atfa da rastlanmamıştır. Sayısal olarak onlardan gelen tefsir, yorum ve rivayetlerin azlığı araştırmamızı sınırlayan âmillerdendir. Bu durum, dönemin sosyo-kültürel yapısı da göz önünde bulundurularak değerlendirmeye tabi tutulmuş ve Hz. Âişe'nin ilminin aktarıcısı kabul edilen Amre'nin, Hz. Âişe'nin bir diğer talebesi Urve b. Zübeyr'e (öl. 94/713) kıyasla çok daha az rivayetinin kaydedilmesi gibi spesifik durumlar kritik edilmiştir. Günümüz araştırmalarında, erken dönem kadınların ilmî hayattaki yerlerine yeterli ölçüde değinilmemiş olmasından hareketle, bu araştırmayla ilk asırda Medine'de, kadınların eğitim-öğretim hayatındaki yerleri ve tefsire katkıları hakkında genel bir kanaate ulaşma hedeflenmiştir.

\section{Anahtar Kelimeler}

Tefsir, Medine, Sahâbe, Tâbiûn, Kadın

\section{Giriş}

Hz. Peygamber, kadınların gerek ibadet gerek ilim tahsili için mescitlerde bulunmalarını önemsemiş, ashâbına "Kadınlarınız mescitlere gitmek için sizden izin istedikleri zaman onları engellemeyin." buyurmuş, erkekler gibi kadınlar da Mescid-i Nebevî̀de namazlara katılarak ${ }^{2}$ dine dair bilgilerin öğrenilmesi ve icrası hakkında istifade etmişlerdir. Kaynaklarda geçen rivayetlere göre kadınların, ibadetlere iştiraklerinin yanı sıra ilim tahsilinde de istekli oldukları ve onlara bu imkânın tanındığı anlaşılmaktadır. Bir gün kadınlar “Ey Allah'ın Rasûlü! Erkeklerden bize imkân kalmıyor. Bizim için özel bir gün ayıramaz mısın?" demişler, Hz. Peygamber de bir gün belirleyerek onların eğitimine tahsis etmiştir. Ümmü Hişâm bint el-Hârise b. Nưmân'ın “Kāf1 (sûresini) bizzat Rasûlullah’tan ezberledim. Zira o her cuma hutbede bu sûreyi okurdu." sözü kadınların aktif bir şekilde Mescid'de bulunduklarını göstermektedir. Onlar, karşılaștıkları bir sorunu, merak ettikleri bir konuyu ya da haksızlığa uğradıkları bir durumu Hz. Peygamber'e arz ediyor ve İslâmî esasları, dinin kuralları ile emir ve yasaklarını öğrenmede iștiyaklı davranıyorlardı. "Hz. Ömer'in bir gün, kadınlara fazla mehir verilmemesi üzerine hutbe irad ettiğini işiten bir kadının en-Nisâ 4/20. âyeti okuyarak halifeye itiraz etmesi" örneğinden hareketle sahâbe döneminde de Peygamber (s.a.s) uygulamalarının devam ettiği ve kadınların, dinin emrettiği emiryasaklar ile kendilerine tanıdığı haklara muttali oldukları anlaşılmaktadır.

1 Ebü'l-Hüseyn Müslim b. el-Haccâc, Sahîhu Müslim, thk. Muhammed Fuâd Abdülbâkī (Kahire: Dâru İhyâü'lKütübi'l-'Arabiyye, 1412/1991), "Salât", 134; Ahmed b. Hanbel, Müsned, thk. Şuayb el-Arnaût - Âdil Mürşid (Beyrut: Müessesetü’r-Risâle, 1416/1995), 9/79.

2 Muhammed b. İsmâil el-Buhârî, el-Câmiu's-sahîh, thk. Muhammed Züheyr b. Nâsır (Beyrut: Dâru Tavki'nNecât, ts.), "Salât", 2, 13, “'̂̂deyn", 7.

3 Buhârî, el-Câmiu’s-sahîh, “ìlim”, 35; “ì'tisâm”, 9; Müslim, Sahîhu Müslim, Birr ve's-sılâ ve'l-âdâb, 152.

4 Ebû Dâvûd es-Sicistânî, Kitâbü's-Sünen, thk. Şuayb el-Arnaût - Muhammed Kamil Karabelli (Dârü'r-Risâleti'l'Âlemiyye, 1430/2009), "Salât”, 228.

5 Ahmed b. Hüseyn el-Beyhakī, es-Sünenü'l-kübrâ, thk. Muhammed Abdülkādir Atâ (Beyrut: Dârü'l-Kütübi'l'ilmiyye, 1424/2003), 7/380. İlgili âyet meali şöyledir: "Bir eşinizin yerine başka bir eş almak isterseniz, ilkine yüklerle mal vermiş olsanız bile ondan hiçbir şeyi geri almayını. Ona iftira ederek ve apaçık günaha girerek mi verdiğinizi geri alacaksınız?" 
Hz. Peygamber'in, ferdî ve ictimâî hayatı şekillendiren bu uygulamaları gerçekleştirdiği şehir olan Medine, sahâbe ve tâbiûn dönemlerinde de ilmî faaliyetlerin yoğun bir şekilde sürdürüldüğü önemli bir ilim merkezidir. Onu, dönemin şehirleri arasında ayrıcalıklı kılan; Mescid-i Nebevî etrafında şekillenen canlı bir ilmî hayatın yaşanması, hulefâ-i râşidin döneminin son zamanlarına kadar yönetim merkezi olması, sahâbenin ve onların elinde yetişen tâbiûn-i kebîrin çok büyük bir kısmının burada ikamet etmesi, Acem nüfusun azlığı ve farklı kültürlerle çok fazla karşılaşılmamış olması dolayısıyla yoğun itikâdî ve amelî tartışmalardan nisbeten uzak kalması gibi birçok hususiyeti bulunmaktadır. Fıkıhta amel-i ehl-i Medine ve fukahâ-i seb'a ile haklı bir şöhret kazanması, hadislerin resmî tedvininde Medineli ulemâya başvurulması, siyer ve megāzîde yine Medineli isimlerin öncü olması gibi özellikleri de Medine'yi özel kılmaktadır. İşte bu önemli şehir, kadınların ilmî hayata katılımı için de imkân sunmaktaydı. Bu çalışmada, ders halkalarında ilimle meşgul olan ve tefsir kaynaklarında belli oranda rivayeti bulunan Medineli kadın sahâbe ve tâbiûn ele alınmıştır. Konuyla ilgili daha önce müstakil bir araştırmanın yapılmamış olması çalışmanın gerekliliğini göstermektedir. Diğer taraftan, tabakāt kitaplarında Medineli kadın sahâbe ve tâbiûn hakkında geniş malumat bulunmaması ve tefsir eserlerinde sınırlı sayıda kadın âlimin rivayetlerinin yer alması araştırmayı zorlaştıran etkenler arasındadır.

\section{Kadın Sahâbîler ve Tefsire Katkıları}

Sahâbeden tevârüs edilen ilmî miras; Hz. Peygamber'in tefsiri ile sebeb-i nüzûl, siyer ve megāzîye dair bilgileri aktarması ve tâbiûn tefsirinin şekillenmesini sağlaması açısından önemli olduğu gibi, günümüz sahih Kur'an yorumu için de vazgeçilmez bir kaynaktır. Zeyd b. Sâbit’ten gelen “Bir gün Rasûlullah'ın dizi benim dizimin üzerindeydi ve birden dizi ağırlaşmaya başladı öyle ki, neredeyse dizim kırılacak sandım ve âyet-i kerîme nâzil oldu." ${ }^{\prime 2}$ rivayetinden anlaşıldığı üzere ashâb, vahyin nüzûlüne bizzat şahit olmakta ve Hz. Peygamber'in tedrisinden geçmekteydiler. Abdullah b. Mes'ûd'un "Bizden biri on âyet öğrendiğinde, bu on âyetin mânasını iyice öğrenmeden ve onunla amel etmeden yeni âyet öğrenmeye geçmezdi."7 sözü, onların Kur'an'1; hıfz, anlama ve amel şeklinde bir yaklaşımla öğrendiklerini ve hayatlarına tatbik ettiklerini göstermektedir.

Kadın sahâbe arasında kuşkusuz Hz. Peygamber'in hanımlarından Hz. Âişe, Hz. Hafsa ve Hz. Ümmü Seleme ilmiyle ön plana çıkmaktadır. Bizzat Hz. Peygamber'den öğrendikleri sayesinde büyük bir ilme sahip muksirûn ve fakih Hz. Âişe'nin tefsire katk1sı azımsanmayacak kadar çoktur. "Sahâbe herhangi bir konuda şüphe ettiğinde Âişe'ye sorarlardı ve sordukları hususta mutlaka onun bir bilgisi olurdu." şeklindeki rivayet onun ilminin genişliğini ortaya koymaktadır. Hz. Âişe'den hemen hemen her belde ule-

\footnotetext{
Buhârî, "Salât", 12; "Cihad”, 31; Ebû Dâvûd, "Cihad”, 19.

Muhammed b. Cerîr et-Taberî, Câmi'u'l-beyân 'an te'vili âyi'l-Kur'ân, thk. Mahmûd Muhammed Şâkir - Ahmed Muhammed Şâkir (Kahire: Mektebetü Ibn Teymiyye, ts.), I, 80.

8 Celâlüddin es-Süyûtî, el-Ittkān fi 'ulûmi'l-Kur'ân, thk. Merkezü'd-Dirâseti'l-Kur'âniyye (Medine, ts.), 2/468.

9 Muhammed İbn Sa'd, et-Tabakātül'-kebîr, thk. Ali Muhammed Ömer (Kahire: Mektebetü'l-Hancî, 1421/2001), $2 / 322$.
} 
ması rivayette bulunmuştur. Bu durumda şüphesiz, Hz. Aişe'nin diğer sahabeye göre daha uzun ömür sürmesi ve çok kere hacca gitmiş olmasının etkisi vardır. Zira hac mevsimi, ibadetin yanı sıra âlimlerin bir arava geldiği ve ilim alısverișinde bulunduğu çok kıymetli bir zaman dilimidir. Ondan nakleden hanımlar arasında; kardeși Abdurrahman'ın (öl. 53/673) kızları Hafsa ve Esmâ ile ablası Esmâ bint Ebû Bekr, Âișe bint Talha, Hz. Ümmü Seleme'nin mevlâsı, Hasan Basrînin annesi Havre ve onun ilminin en kuvvetli aktarıcısı olduğu söylenilen Amre bint Abdurrahman sayılabilir. Câmi'u'l-bevân'da en sık rastlanan tâbiî ravileri; Urve b. Zübeyr, Kāsım b. Muhammed (öl. 107/725), Abdullah b. Mes'ûd'un (öl. 32/652) önde gelen talebeblerinden Âmir b. Şerâhîl eş-Şa‘bî (öl. 104/722), Mekkeli müfessirler arasında zikredilen Atâ b. Ebû Rebâh (öl. 114/732), Basralı meşhur müfessir Katâde (öl. 117/735), muhadramûndan Mesrûk b. Ecdâ‘ (öl. 63/683) ve Hişâm b. Urve b. Zübeyr'dir (öl. 146/763). ${ }^{10} \mathrm{~Hz}$. Aișe ravileri arasında fukahâ-i seb'a'dan Urve b. Zübeyr'in özel bir yeri vardır. Onun, Hz. Peygamber'den rivayet ettiklerinin dörtte üçü Urve kanalıyla gelmektedir. ${ }^{11}$ Urve, aynı zamanda teyzesi de olan Hz. Âişe için “Kur'ân'1, ferâizi, helâl ve haramı Âişe'den daha iyi bileni görmedim." demektedir. ${ }^{12}$ Ravileri arasında dikkat çeken bir diğer isim bir sonraki başlıkta değinilecek olan Amre bint Abdurrahman'dır ki; Hz. Âişe'nin ilmine sahip olma yönünden Urve ile kıyaslanmıştır. Kendisine ait bir mushafı da olan ${ }^{13} \mathrm{~Hz}$. Âişe'nin Câmi'u'l-beyân'da üç yüzü aşkın rivayeti vardır ve bu rivayetlerin yarısına yakını Hz. Peygamber'den merfư' olarak nakledilmektedir. Bunun yanı sıra kendi içtihadıyla da âyetleri tefsir etmekte, lugavî izahlar, sebeb-i nüzûl, kıssa ve kıraatlere dair bilgi vermektedir. Tefsirinin en belirgin özelliği ise fikhî açıklamalarıdır. "Gözler O'nu idrak edemez; O ise bütün gözleri görür." (el-En'âm 6/103) âyetini, "Allah bir insanla ancak vahiy yoluyla veya perde arkasından konuşur, ya da bir elçi gönderir de izniyle ona dilediğini vahyeder." (eş-Şûrâ 42/51) âyetiyle izah etmesi örneğinde olduğu gibi Kur'ân'1 Kur'ân'la; ${ }^{14}$ oruç emrinden bahsedilen el-Bakara 2/185. âyeti, "Hamza, Rasûlullah'a yolculukta oruç tutup tutamayacağını sorunca, Rasûlullah 'İster tutarsın, ister tutmazsın.' dedi.” rivayetindeki gibi sünnetle; “15 “Allah'ın açı̆̆a vuracağı şeyi gizliyor, insanlardan çekiniyordun."16 âyetiyle ilgili ise "Hz. Peygamber Kur'ân'dan bir şey gizleyecek olsaydı bu âyeti gizlerdi."17 diyerek kendi yorumuyla tefsir etmektedir.

Hz. Âişe'den sonra Peygamber hanımları arasında en çok hadis rivayet eden Hz. Ümmü Seleme'dir. Ümmü Seleme, Medine'de Kur'ân öğreten özel mushaf sahibi kurrâ

10 Sevgi Tütün, et-Taberînin Câmi'u'l-beyân İsimli Eserinde Hz. Aişe'den Yapllan Rivayetlerin Tesbiti ve Değerlendirilmesi (İzmir: Dokuz Eylül Üniversitesi, Sosyal Bilimler Enstitüsü, Yüksek Lisans Tezi, 1999), 19-23.

11 Abdullah Ebüssuûd Bedr, Tefsîru ümmi'l-mü'minîn Aişe (Riyad: Dâru Âlemi'l-Kütüb, 1416/1996), 44.

12 Bedr, Tefsîru ümmi'l-mü'minîn Aişe, 78.

13 Buhârî, el-Câmiu's-sahîh, "Fezîlü'l-Kur'ân", 6.

14 Taberî, Câmi'u'l-beyân, 12/16.

15 Taberî, Câmitu'l-beyân, 3/470.

16 el-Ahzâb 33/37.

17 Ebü'l-Fidâ İbn Kesîr, Tefsîrü'l-Kur'âni'l-'azîm, thk. Sâmî b. Muhammed es-Selâme (Riyad: Dâru Tayyibe, 1420), $6 / 425$. 
sahâbîlerdendir. ${ }^{18}$ Ümmü Seleme'nin Câmi'u'l-beyân'da elliyi aşkın rivayeti bulunmaktadır. Onun tefsir rivayetleri, Hz. Peygamber'in tefsirini ihtiva etmesi açısından son derece önemlidir. Aynı zamanda sebeb-i nüzûl, vakf ve ibtida, müteşâbihât, nesh gibi Kur'ân ilimlerine dair mâlumat vermekte ve hamile kadının iddeti, süt emzirme hükümleri gibi fikhî açılamalarda bulunmaktadır. ${ }^{19}$ Ümmü Seleme'nin fikhî konulardaki donanımı ve isabetli izahları dikkat çekmektedir. Örneğin, Hudeybiye anlaşmasının ardından $\mathrm{Hz}$. Peygamber'e yaptığ 1 tavsiyede bunu görmek mümkündür. Anlaşmadan sonra ashâb, umduğunu bulamamış, âdeta yenilgiye düşülmüş gibi Mekkeli müşriklerin isteklerinin kabul edilmesine üzülmüş bu sebeple Hz. Peygamber' in kurbanlarını kesmeleri ve tıraş olmaları yönündeki emrini ilk başta yerine getirmemişlerdir. Bunun üzerine Ümmü Seleme, Hz. Peygamber'e kurban kesip tıraş olmasını tavsiye ederek, kendisinin yaptığı takdirde ashâbının da yapacağı yönünde teşvik ve telkinde bulunmuş, nitekim onun öngörüsünde olduğu gibi Müslümanlar Hz. Peygamber'in ardından kurbanlarını kesip tıraşlarını olmuşlardır. ${ }^{20}$

Ümmü Seleme'nin tefsir rivayetlerinden birisi; "Saklı inciler gibi iri gözlü hûriler"21 âyeti hakkındadır: “Ey Allah'ın Rasûlü, Allah'ın 'iri gözlü hûriler' kavline dair bana bilgi

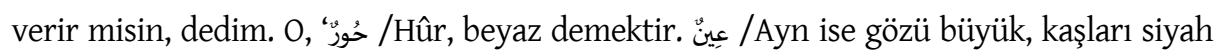

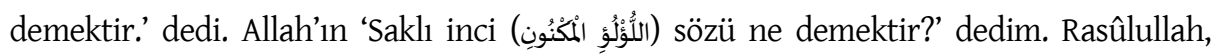
'Onların parlaklıkları, sedef içerisinde olup da el değmemiş inci parlaklığındadır.' buyurdu." ${ }^{\text {22 }}$ Bu örnek Peygamber (s.a.s) tefsirini kapsamaktadır. Onun "Biz kadınların Allah katında bir payı yok mudur? Niçin Kur'ân'da bizden bahsedilmiyor?" şeklindeki sözü üzerine; "Rableri onlara şu karşıllı̆ı verdi; "Ben, erkek ya da kadın olsun, sizden hiçbir çalışanın amelini zayi etmeyeceğim." ${ }^{23}$ âyeti ile "Müslüman erkeklerle Müslüman kadınlar, mü'min erkeklerle mü'min kadınlar, itaatkâr erkeklerle itaatkâr kadınlara ... Allah mağfiret ve büyük bir mükâfat hazırlamıştır." ${ }^{24}$ âyetinin nâzil olduğu ifade edilmiştir. ${ }^{25}$

Hz. Peygamber'in bir diğer eşi hafız ve kurrâ sahâbeden Hafsa bint Ömer de okuma bilmekte ve kendisi için yazdırdığı bir mushafının olduğu kaydedilmektedir. ${ }^{26} \mathrm{~Hz}$. Ebû Bekir (öl. 13/634) döneminde vahiy kâtibi Zeyd b. Sâbit (öl. 45/665) riyasetinde toplanıp mushaf haline getirilen Kur'ân, Ebû Bekir'den sonra Hz. Ömer (öl. 23/644) tarafından

18 M. Yaşar Kandemir, “Ümmü Seleme”, Türkiye Diyanet Vakfi İslâm Ansiklopedisi (İstanbul: TDV Yayınları, 2012), 42/ 329; Serpil Başar, “Ümmü Seleme’nin Tefsir Rivayetlerinin Değerlendirilmesi”, Dokuz Eylül Üniversitesi İlahiyat Fakültesi Dergisi 36 (Şubat 2012), 429.

19 Misaller için bk. Başar, “Ümmü Seleme'nin Tefsir Rivayetlerinin Değerlendirilmesi”, 431-436, 440.

20 Taberî, Câmi'u'l-beyân, 3/39; Muhammed b. Ahmed el-Kurtubî, el-Câmi li-ahkâmi'l-Kur'ân ve'l-mübeyyin lemâ tedammenehu mine's-sünneti ve âyil-Furkân, thk. Abdullah b. Abdilmuhsin et-Türkî (Beyrut: Müessesetü'rRisâle, 1467/2006), 19/328.

21 el-Vâkı 56/22-23.

22 İbn Kesîr, Tefsîrü'l-Kur'âni'l-‘azîm, 7/532.

23 Âl-i İmrân 3/195.

24 el-Ahzâb 33/35.

25 Mukātil b. Süleyman, Tefsîru Mukātil, thk. Abdullah Mahmûd Şehhâte (Beyrut: Müessesetü't-Târîhi'l-'Arabî, 1423/2002), 1/322.

${ }^{26}$ Muhammed b. İsmâil el-Buhârî, et-Târîhu'l-kebîr (Haydarabad: Dâiretü'l-Maârifi'l-Osmâniyye, 1958), 3/1, 281; Süyûtî, İtkān, 2/468. 
muhafaza edilmiş, Hz. Ömer vefat edince ise Hz. Hafsa'nın korumasına verilmiştir. Hz. Osman, mushafın istinsahında bu nüshayı Hafsa'dan istetmiş, istinsah işi bitince ise kendisine iade etmiştir. ${ }^{27} \mathrm{~Hz}$. Ömer'in mevlâsı tâbiînden Amr b. Râfi', ${ }^{28}$ Abdullah b. Ömer'in (öl. 73/693) hanımı Safiyye bint Ebû Ubeyd, ${ }^{29}$ Abdullah b. Ömer'in oğlu Sâlim (öl. 106/725) ve mevlâsı Nâfi' (öl. 117/735) gibi tâbiîler, Hafsa'dan rivayette bulunmaktadır. "Hani peygamber eşlerinden birine bir sır vermişti. Fakat eşi o sırrı başkasına haber verince, Allah bu durumu nebisine bildirmiş, Peygamber de o sırrın bir kısmını açıklamış bir kısmını ise haber vermemişti. (Sır verdiği eşine) haber verince o, "Bunu sana kim bildirdi?' dedi. O da 'Bunu bana, alîm ve habîr olan Allah bildirdi.' dedi." (et-Tahrîm 66/3) âyetinde bahsedilen hanımın da Hz. Hafsa olduğu ifade edilmiştir. ${ }^{30}$ Amr b. Râfi'nin naklettiğine göre, Hafsa ondan kendisine mushaf yazmasını istemiş ve "Bana bir mushaf yaz,

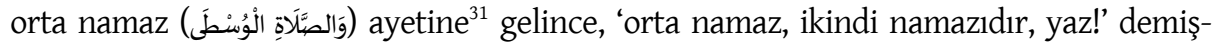
tir." 32 Mushafının kenarına düştüğü bu notlar onun tefsir hususiyetlerini yansitmaktadır. Peygamber (s.a.s) bir gün, "Bedir ve Hudeybiye'ye şahit olan hiç kimsenin cehenneme girmeyeceğini ümit ediyorum.” buyurunca Hz. Hafsa, “Ey Allah'ın elçisi! Allah, 'Sizden cehenneme girmeyecek hiç kimse yoktur. ${ }^{33}$ buyurmaktadır." deyince Hz. Peygamber (bu âyetin devaminda yer alan âyeti kastederek) "Sen Allah'ın 'Sonra muttaki olanları kurtarırız. Zalimleri ise diz üstü çökmüş olarak orada bırakırız.' ${ }^{34}$ buyurduğunu işitmedin mi?" şeklinde cevapladığı rivayeti de bizzat Hz. Peygamber'den Kur'ân mânaların1 sorup öğrendiğini gösteren misallerden biridir. ${ }^{35}$

Medine'de Hz. Peygamber hanımları haricinde eș-Şifâ bint Abdullah, Ümmü Varaka bint Abdullah b. Hâris, Esmâ bint Yezîd, Esmâ bint Ebû Bekr es-Siddîk ve Semra bint Nüheyk gibi ilim sahibi birçok kadın sahâbe daha bulunmaktadır. Tefsir kaynaklarında sınırlı sayıda rivayeti bulunan bu hanımlardan eş-Şifâ Ümmü Süleyman b. Ebû Hayseme olarak da adlandırılan Şifâ bint Abdullah; ilk hicret edenlerden olup, yazı bilen az sayıda sahâbe arasında yer almaktadır. Hz. Peygamber onu muhtesip olarak çarşı-pazar denetlemeyle görevlendirmiştir. Bir rivayette Hz. Peygamber Şifầya, "Hafsa'ya yazmayı öğret-

27 Buhârî, el-Câmiu's-sahîh, "Fezâilü'l-Kur'ân”, 3; Taberî, Câmi“u'l-beyân, 1/60-61; Süyûtî, İtkān, 2/388.

28 Medine ehlinin ilk tabakasındandır. Hz. Hafsa'nın mevlâsı olduğu da ifade edilmiştir. bk. Moğultay b. K1lıç, İkmâlü Tehzîbi'l-Kemâl fi esmâi'r-ricâl, thk. Âdil b. Muhammed - Üsâme b. İbrâhim (Kahire, 1422/2001), $10 / 168$.

29 Sahâbî olduğu da söylenmiştir ancak tâbiûndan olması daha doğrudur (Taberî, Câmi'u'l-beyân, 5/82.).

30 Elmalılı Muhammed Hamdi Yazır, Hak Dini Kur'an Dili (İstanbul: Zehraveyn, ts.), 8/153.

31 el-Bakara 2/238.

32 Buhârî, et-Târîhu'l-kebîr, 3(1)/281; Taberî, Câmi'u'l-beyân, 5/213; Ahmed b. Muhammed es-Sa'lebî, el-Keşf ve'lbeyân 'an tefsîri'l-Kur'ân, thk. Ebû Muhammed b. Âşûr (Beyrut: Dâru İhyâü’t-Türâsi'l-Arabî, 1422/2001), 6/227. Benzer rivayet Ümmü Seleme için de zikredilmektedir (Taberî, Câmi'u'l-beyân, 5/176).

33 Meryem 19/71.

34 Meryem 19/72.

35 İbn Kesîr, Tefsîrü'l-Kur'âni'l-'azîm, 7/336. Hz. Hafsa, Kur'ân kıraatinde önemli bir yere sahiptir. Mâtürîdî (öl. 333/944) tefsiri onun kıraat vecihlerine en geniş yer veren tefsirdir. Ayrıntılı bilgi için bk. Nesrişah Saylan, “Hz. Hafsa'ya Nisbet Edilen Kıraat Vecihlerinin Mâtürîdî Tefsiri Bağlamında İncelenmesi”, Dinbilimleri Akademik Araştırma Dergisi 20/1 (Mart 2020)/402. Hz. Peygamber'in diğer eşleri, ilmî hayattaki durumları ve tefsire katkılarına dair bilgi için bk. Hidayet Aydar, Hanım Müfessirler (İstanbul: Ensar Neşriyat, 2015), 57-87. 
tiğin gibi karınca rukyesini de öğretsene." demiş̧ir. ${ }^{36}$ Onun gibi çarşı-pazar denetleme ve "emr-i bi'l-ma'rûf nehy-i ani'l-münker" vazifesivle görevlendirilen muammerûndan Semra bint Nuhevk de vardır. ${ }^{37}$ Kur'ân'ı ezberleven âlim sahâbe arasında zikredilen Ümmü Varaka ${ }^{38}$ ise Allah Rasûlü'nden sehit olma ümidivle Bedir'e katılmak için izin talep etmis, Pevgamber Efendimiz ise ona evinde kalmasını ve Rabbinin iznivle sehit sevabı kazanacağını salık vermiştir. Ümmü Varaka, yine Hz. Peygamber'in emriyle ev halkına imamlık da yapmışıır. ${ }^{39}$ Bir diğer sahâbî Ümmü Seleme el-Ensâriyye diye de bilinen Esmâ bint Yezîd; âkil, fazilet sahibi ve dindar bir kadındır. Bey atü'r-rıdvân'da Hz. Peygamber'e biat eden ensar arasında yer almıştır. Kadınların elçisi olarak Hz. Peygamber'e yönelttiği "Biz kadınlar, eşlerimizi memnun ediyor, çocuklarımıza bakıyor ve ev işlerini üstleniyoruz. Erkekler ise cuma namazına gidiyor, cenaze ve cihadda hazır bulunuyorlar. Biz onlara bu işleri dolayısıyla verilecek sevaplarına ortak olabilecek miyiz?" şeklindeki soru, Hz. Peygamber'in hoşuna gitmiş ve onu övmüştür. ${ }^{40} \mathrm{~Hz}$. Zübeyr b. Avvâm'ın (öl. 36/656) eşi, Hz. Ebû Bekir'in kızı Esmâ bint Ebû Bekr ise, Hz. Âişe'nin ablası olması hasebiyle Hz. Peygamber'in sünnetini yakinen öğrenebilme şansını yakalamıştır. ${ }^{41}$ Çocuklarından Abdullah b. Zübeyr (öl. 73/692) sahâbî, Urve ise tâbiûnun meşhur âlimlerdendir. Kütüb-i sitte gibi muteber hadis kaynaklarında rivayetleri bulunmaktadır. "Allah, din konusunda sizinle savaşmayan ve sizi yurdunuzdan çıarmayanlara iyilik yapmanızı ve onlara adaletli davranmanızı yasaklamaz." ${ }^{" 2}$ âyetinin Esmâ hakkında nazil olduğu ifade edilmiştir. Medine günlerinde iken henüz Müslüman olmamış annesini eve almakta ve onun kendisine getirdiği hediyeleri kabul etmekte tereddüt gösteren Esmâ, Hz. Peygamber'e durumu arz ettiğinde ilgili âyetin indirildiği ifade edilmiştir. ${ }^{43}$ Farklı tefsir kaynaklarında onun rivayetlerini görmek mümkündür. Örneğin; en-Necm 53/14. âyetle ilgili “Hz. Peygamber'den işittim ki sidretü'-müntehâ için yüz yolcu o ağacın dallarının gölgesi altında yürüyordu/orada ağırlanıyordu, buyurmuştur." demektedir. ${ }^{44}$ Yine ashâbın Kur'an okunduğunda ne yaptıkları sorulunca, onların gözlerinden yaşlar akarak Allah'a yalvardıklarını ve ez-Zümer 39/23. âyette buyrulduğu üzere âdeta tüylerinin

36 Ebû Dâvûd, "Tib”, 18; Yûsuf b. Abdullah en-Nemerî İbn Abdülber, el-istitiâb fi ma rifetil'-ashâb, thk. Âdil Mürşid (Ürdün: Dârü'l-A'lâm, 1423-2002), 915; Ömer Rıza el-Kehhâle, A'lâmü'n-nisâ' fi'l-âlemeyil'-Arab ve'l-Isslâm (Beyrut: Müessesetü'r-Risâle, ts.), 2/300-301. "Hastalık ve kötülüklerden korunmak veya kurtulmak amacıyla dua okuyup üfleme” mânasına gelen rukyenin dindeki durumu, Hz. Peygamber'in yasaklama veya cevaz vermesiyle ilgili rivayetlerin değerlendirilmesiyle ilgili bk. i̇lyas Çelebi, "Rukye", Türkiye Diyanet Vakfi İslâm Ansiklopedisi (istanbul: TDV Yayınları, 2008), 35/ 219-222.

37 Ebû Dâvûd, Kitâbü's-Sünen, “Tib”, 18; İbn Abdülber, el-İsttîâb, 914; Kehhâle, Alâmün-nisâ, 2/260.

38 Süyûtî, İtkān, 2/472.

39 Kehhâle, A'lâmü’n-nisâ, 5/284-285. Sahâbî Sa'de bint Kumâme'nin de hanımlara imamlık yaptığı ifade edilmiştir (İzzeddin Ali b. Muhammed İbnü'l-Esîr, Üsdül'-gābe fi márifetti's-sahâbe, thk. Muhammed Muavvid Âdil Ahmed Abdülmevcûd (Beyrut: Dârül'-Kütübi'l-'ilmiyye, ts.), 7/142.)

40 İbn Abdülber, el-İstîâab, 873; Ebû Abdurrahman Hâlid b. Hüseyn, Câmi'u ahbâri'n-nisâ' min Siyeru a'lâmi'n-nübelâ (Riyad: Mektebetü’r-Rüşd, 1425/2004), 372; Kehhâle, A'lâmü'n-nisâ, 1/66-67.

${ }^{41}$ İbn Sa'd, et-Tabakātü'l-kebîr, 10/237.

42 el-Mümtehine 60/8.

43 İbn Kesîr, Tefsîrü'l-Kur'âni'l-'azîm, 8/90.

${ }^{44}$ Muhammed b. Cerîr et-Taberî, Câmi'u'l-beyân 'an te'vili âyi'l-Kur'ân, thk. Abdilmuhsin et-Türkî (Kahire: Dâru Hicr, 1422/2001), 22/38; Sa'lebî, el-Keşfve'l-beyân, 9/143. 
ürperip derilerinin çekildiğini söylemektedir. ${ }^{45}$ Tebbet sûresinin nüzûl sebebi hakkında ise; sûrede zikredilen ve Ebû Leheb'in eşi olan Ümmü Cemîl'in Hz. Peygamber'e vurmak üzere elinde taşla öfkeli bir şekilde Kâbe'ye yöneldiğini ancak Hz. Peygamber'in “Kur'an okuduğun zaman seninle âhirete inanmayanlar arasına görünmeyen bir perde çekeriz" (el-İsrâ 17/45) âyetini okuduğunu ve bu sayede Ümmü Cemîl'in onu göremediğini, "Zemmedilmiş birine isyan ediyoruz/Onun emirlerinden yüz çeviriyoruz/Dininden nefret ediyoruz" sözleriyle Hz. Peygamber'i hicvederek oradan ayrıldığını aktarmaktadir. ${ }^{46}$

\section{Kadın Tâbiîler ve Tefsire Katkıları}

Tâbiûn dönemi ilmî faaliyetlerin en yoğun devam ettiği şehir şüphesiz İslâm'in toplumsal hayatta da yaşanır hale geldiği ve İslâm devletinin kurulduğu Medine'dir. Hz. Peygamber döneminde elde ettiği otoriteyi uzun ylllar koruyan Medine, ilimlerin merkezi olma ayrıcalığını tâbiûn döneminde de sürdürmüştür. Sahâbenin tedrisinden geçen tâbiûn, onlardan aldıkları ilmî mirası kendilerinden sonraki nesillere özenle aktarmış, vârisi oldukları kültürü yeni yorum ve ilmî birikimleriyle zenginleştirmiştir. Tefsire katkı sunan birçok isim Medine'nin ilmî ortamından istifade etmiş, gittikleri beldelerde ilim halkaları kurarak öğrenciler yetiştirmiştir. Tefsirde adına sıklıkla rastlanan başta Muhammed b. Ka'b el-Kurazî (öl. 118/733) ve Zeyd b. Eslem (öl. 136/754) olmak üzere Urve b. Zübeyr, Saîd b. Müseyyeb (öl. 94/713), Ömer b. Abdülazîz (öl. 101/720), Atâ b. Yesâr (öl. 103/721), Nâfı̊ mevlâ İbn Ömer, Muhammed el-Bâkır (öl. 114/733) ve İbn Şihâb ez-Zührî (öl. 124/742) gibi meşhur tâbiûn Medinelidir.

Kadın tâbiûn hakkında bilgi vermeden önce bu konuyu ele alırken karşılaştı̆̆ımız birtakım engellere kısaca değinmek istiyoruz. Klasik kaynaklarda, tabakāt ve terâcim türü eserlerde, kadın sahâbe ve tâbiûn hakkında yeterli bilginin yer almamış olması, vefat tarihlerinin dahi çok az kaynakta zikredilmesi karşılaşılan ilk engeldir. Bu kaynaklarda, haklarında etraflı bilgiye ulaşmak zor olduğu gibi ilmî hayatlarına dair malumat da verilmemiş, tefsire katkıları açısından ise hiçbir kayıt ya da değerlendirme düşülmemiştir. ${ }^{47}$ Son dönemde kaleme alınmış Ahmed Halil Cum'a'nın Nisâ' min asri't-tâbi înn ${ }^{48}$ adlı eseri konumuzla doğrudan ilişkili olmakla beraber, eserde klasik kaynaklardaki bilgilerin bir araya getirilmesinden öteye gidilememiş; yazar, herhangi bir yorum ya da değerlendirmede de bulunmamıştır. Aynı zamanda çalışmada akademik dil yerine daha çok edebî

45 Sa'lebî, el-Keşfve’l-beyân, 8/231.

46 Abdurrahman b. Muhammed İbn Ebû Hâtim, Tefsîrül-Kur'âni'l-'azîm müsneden 'an Rasûlillah ve's-sahâbe ve'ttâbi în, thk. Esad Muhammed Tayyib (Riyad: Mektebetü Nizâr Mustafa el-Bâz, 1417/ 1997), 10/3472; Kurtubî, el-Câmi' li-ahkâmi'l-Kur'ân, 13/ 92; İbn Kesîr, Tefsîrü'l-Kur'âni'l-'azîm, 5/82

47 Klasik ve modern eserlerin, kadın tâbiûnun tefsirle ilişkilerine yer verip vermedikleriyle ilgili değerlendirmeler için bk. Aydar, Hanım Müfessirler, 27-56. Tefsir tarihi çalışmalarındaki eksiklikler ve bu çalışmalarda kadın müfessirlere yer verilmemesiyle ilgili eleştiriler için bk. İsmail Çalışkan, "Tefsir Tarihi Tasavvurunun Yeniden İnşasının Gerekliliği Üzerine”, İslâmiyât Dergisi 8/1 (2005), 11-23. Hadis ilminde kadın tâbiûnun hakkında bk. Nusrettin Bolelli, Kadınların Hadis İlmindeki Yeri (İstanbul: Marmara Üniversitesi İlahiyat Fakültesi Vakfi Yayınları, 1998), 3-12.

48 Ahmed Halîl Cum‘a, Nisâ’ min asri’t-tâbi în (Dımaşk: Dâru İbn Hazm, 1416/1996). 
dil kullanılması ve sahâbe isimleri geçtiğinde zikredilen dua cümlelerinin uzunluğu gibi hacmi arttırıcı ancak esasa taalluk etmeyen ziyade cümlelerin bulunması bu çalışmadan istifadeyi zorlaştırmaktadır. Serpil Başar'ın Erken Dönemde (Hicrî I. Asır) Kadınların Kur'an Yorumuna Katkları adlı önemli tez çalısması ise kadın sahâbeyi ve sahâbe arasında da özelikle Hz. Âişe'yi incelemekte, yer yer kadın tâbûnun görüşlerine atıf yapmaktadır. Hidayet Aydar'ın Hanım Müfessirler adlı kitabı bu alandaki ilk eser özelliği taşımakla birlikte sahâbeden günümüze kadar uzun bir süreci ve bu süreçteki kadın müfessirleri incelediğinden tâbiûn dönemi hakkında ayrıntıya girilmediği bununla birlikte kıymetli bilgilerin verildiği önemli bir çalışmadır. ${ }^{49}$ Medineli tâbiî kadınlar hakkında müstakil bir çalışma bulunmamaktadır. Aynı durum, Mekke, Basra ve Kûfe gibi diğer bölgeler için de gözlenmektedir.

Tâbiûn dönemi Medine'de başta Hz. Âişe olmak üzere sahâbeden ilim tahsil eden âlim kadınlardan; Ümmü Külsûm bint Ebû Bekr; Zeyneb bint Ali b. Ebû Tâlib; Hafsa bint Abdurrahman b. Ebû Bekr es-Sıddîk, Safiyye bint Ebû Ubeyd, Aişe bint Talha b. Ubeydullah Amre bint Abdurrahman b. Sad, Âişe bint Sa'd b. Ebû Vakkās ve Fâtıma bint elMünzir b. Zübeyr b. Avvâm'nn isimleri sayılabilir. Bu isimlerin tefsir kaynaklarındaki rivayetlerinin son derece az olduğu görülmektedir. Genellikle evlerinde vakit geçiren ve yine evlerindeki ilim halkalarında Kurân, hadis ve fikıh öğrenen kadınların, mescitlerde ilimle iştigal eden erkekler kadar ilmî hayatta rol oynamadıkları aşikârdır. Sayısal olarak onlardan gelen yorum ve rivayetler az olsa da dönemin sosyo-kültürel yapısı da göz önünde bulundurularak, kadınların toplumsal hayatta belli bir yer edindikleri ve eğitimöğretim faaliyetlerine katıldıkları anlaşılmaktadır.

Ümmü Külsûm bint Ebû Bekr es-Sıddîk; Hz. Ebû Bekr'in vefatından sonra doğan en küçük kızıdır. Ablası Hz. Âişe'nin gözetimi altında büyümüş ve onun ilminden pek çok şey öğrenmiştir. Talha b. Ubeydullah (öl. 36/656) Cemel savaşında vefat edinceye kadar onunla evli olan Ümmü Külsûm, aynı zamanda eşinin ilminden de istifade etmiştir. Kendisinden Câbir b. Abdullah (öl. 78/697), tâbiî̀ Ebü'l-Ezher Mugìre b. Hakîm es-San'ânî ile tâbiî Abdullah b. Ubeyd b. Umeyr el-Mekkî (öl. 113/731) rivayette bulunmaktadır..$^{50}$ enNisâ 4/34. âyetin tefsirine dair "Erkeklerin kadınlara vurması yasaklanınca, erkekler Hz. Peygamber'e şikayette bulundular. Bu durum üzerine Allah rasûlü, onları olduğu hal üzere bıraktı ancak 'Sizin hayırlılarınız eşlerine vurmaz' buyurdu." demektedir. ${ }^{51}$

Zeyneb bint Ali b. Ebû Tâlib; Hz. Ali (öl. 40/661) ve Hz. Fâtıma'nın (öl. 11/632) kızlar1, Hz. Hasan (öl. 49/669) ve Hüseyin'in (öl. 61/680) kardeşidir. Eşi sahâbî Abdullah b. Ca'fer b. Ebû Tâlib'dir (öl. 80/669). Onun, bir tefsir meclisi olduğu ve bu meclisteki hanımlara Kur'ân öğrettiği; zeki, bilgili, fesahat ve belagatta ilim sahibi olduğu ifade edil-

${ }^{49}$ Şu çalışma da alana katkı sunmaktadır: Hidayet Aydar - Mehmet Atalay "Female Scholars of Quranic Exegesis in the History of Islam (İslam Tarihinde Kadın Müfessirler)", Bülent Ecevit Üniversitesi Ilahiyat Fakültesi Dergisi 2 (2014), 1-34.

50 Kehhâle, A'lâmü'n-nisâ, 4/251; Bolelli, Kadınların Hadis İlmindeki Yeri, 140; Gülgün Uyar, “Ümmü Külsûm bint Ebû Bekr", Türkiye Diyanet Vakfi İslâm Ansiklopedisi (istanbul: TDV Yayınları, 2012), 42/ 324; Aydar, Hanım Müfessirler, 140.

51 Celâlüddin es-Süyûtî, ed-Dürrü'l-mensûr, thk. Abdullah b. Abdilmuhsin et-Türkî (Kahire 1424/2003), 4/404. 
miştir. Yeğeni Zeynelâbidîn Ali b. Hüseyin b. Ali (öl. 94/712) onun ibadetlerine düşü̈n, âbid ve âlim bir hanım olduğunu söylemektedir. ${ }^{52}$

Hafsa bint Abdurrahman b. Ebû Bekr es-Sıddîk; sika ravilerdendir. Babası Abdurrahman'dan, teyzesi Hz. Âişe'den ve Hz. Ümmü Seleme'den aktarmakta ondan da Irak b. Mâlik (öl. 101/720), Atâ b. Ebû Rebâh, Abdurrahman b. Sâbit el-Cumahî (öl. 118/736) ve Avn b. Abbas rivayet etmektedir. Fıkıh bilgisinde temayüz ettiği kaydedilmiştir. ${ }^{53}$ Safedî’nin (öl. 746/1363) verdiği bilgiye göre 80/699'lu yıllar içerisinde vefat etmiştir. ${ }^{54}$

Safiyye bint Ebû Ubeyd; Abdullah b. Ömer'in hanımıdır. Sahâbeden olduğu da söylenmiş, ${ }^{55}$ çoğunluk ise onu tâbiûndan kabul etmiştir. Eşinden, Hz. Ömer, Âişe, Ümmü Seleme, Hafsa ve fukahâ-i seb'a arasında yer alan Kāsım b. Muhammed'den rivayet etmekte, kendisinden Abdullah b. Ömer'in mevlâsı Nâfi', Sâlim b. Abdullah b. Ömer, Abdullah b. Dînâr (öl. 127/745), Mûsâ b. Ukbe (öl. 141/758) ve Ömer b. Osman b. Abdüddâr el-Kuraşî aktarmaktadır. Buhârî (öl. 256/870), İclî (öl. 261/875), Muhammed b. Hibbân (öl. 354/965) ve Mizzî (öl. 742/1341) gibi hadis ulemasınca sika kabul edilmiştir. ${ }^{56}$ Safedînin verdiği bilgiye göre 90/709'lu yıllar içerisinde vefat etmiştir. ${ }^{57}$ Taberî (öl. 310/923) tefsirinde Allah'a iman eden bir kadının kocasının ardından yas tutmasıyla ilgili aktardığı bir rivayetini tespit edebildik. ${ }^{58}$

Âişe bint Sa'd b. Ebû Vakkās; babası Sa'd b. Ebû Vakkās'tan (öl. 55/675) ve Hz. Peygamber hanımlarının çoğundan rivayette bulunmuş kendisinden Eyyûb es-Sahtiyânî (öl. 131/749), Hakem b. Uteybe (öl. 115/733), Abdullah b. Ubeyde ez-Zebîdî er-Rebezî (öl. 130/747), Ebü'z-Zinâd Abdullah b. Zekvân (öl. 130/748), Sahr b. Cüveyriye, İsmail b. İbrahim b. Ukbe (öl.170/786 civarı), yeğeni Osman b. Abdurrahman el-Vakkāsî (öl. 170/786'dan sonra), Mâlik b. Enes (öl. 179/795), Ubeyde bint Nâbil ve Medine ehlinin ekseriyeti rivayet etmiştir. Sika raviler arasında yer almaktadır. ${ }^{59}$ Babası Sa'd b. Ebû Vakkās'tan yazı yazmayı öğrenmiştir. ${ }^{60}$

Aişe bint Talha; babası sahâbî Talha b. Ubeydullah, annesi ise Hz. Ebû Bekir'in kızı tâbî̂ Ümmü Külsûm'dür. Teyzesi Hz. Âişe'den ilim öğrenmiş, hadis rivayet etmiştir.

52 Hâlid b. Hüseyn, Câmi'u ahbâri’n-nisâ', 259-260; Kehhâle, Alâmü’n-nisâ, 2/92-99; Aydar, Hanım Müfessirler, 8889.

53 İbn Sa'd, et-Tabakātü'l-kebîr, 10/435; İbn Hibbân, Muhammed b. Hibbân b. Ahmed, Kitâbü's-Sikāt, thk. Muhammed Abdülmuîd Han (Haydarabad: Dâiretü'l-Maârifi'l-Osmaniyye, 1393/1973), 4/194; Cemâlüddin Ebü'l-Haccâc Yûsuf el-Mizzî, Tehzîbü'l-Kemâl fi esmâi'r-ricâl, thk. Beşşâr Avvâd Ma'rûf (Beyrut: Müessesetü'rRisâle, 1403/1983-1413/1992), 35/153; Kehhâle, A lâmü’n-nisâ, 1/274.

54 Salâhüddin Halîl b. Aybek es-Safedî, el-Vâfi bi'l-vefeyât, thk. Ahmed el-Arnaût - Tezkî Mustafa (Beyrut: Dâru İhyâü't-Türâsi'l-Arabî, 1420/2000), 13/67.

55 İbn Abdülber, el-İstîâb, 917; İbnü'l-Esîr, Üsdü'l-gābe fìma'rifeti's-sahâbe, 7/172.

56 İbn Sa'd, et-Tabakātü'l-kebîr, 10/483; İbn Hibbân, Muhammed b. Hibbân b. Ahmed, es-Sikāt, 4/386; Mizzî, Tehzîbü'l-Kemâl, 35/213; Kehhâle, A'lâmü’n-nisâ, 2/346.

57 Safedî, el-Vâfi bi'l-vefeyât, 16/190.

58 Taberî, Câmi'u'l-beyân, 5/81.

59 İbn Sa'd, et-Tabakātü'l-kebîr, 10/433; İbn Hibbân, Muhammed b. Hibbân b. Ahmed, es-Sikāt, 5/288-289; Mizzî, Tehzîbü'l-Kemâl, 35/236; Şihâbüddin Ahmed b. Ali b. Hacer el-Askalânî, Tehzîbü't-Tehzîb, thk. İbrahim ezZeybek - Âdil Mürşid (Beyrut: Müessesetü’r-Risâle, ts.), 4/681; Kehhâle, Alâmü’n-nisâ, 2/135.

${ }^{60}$ Ahmed b. Yahyâ el-Belâzürî, Fütûhu'l-büldân, thk. Abdullah Enîs et-Tabbâ‘ - Ömer Enîs et-Tabbâ‘ (Beyrut, 1407/1987), 661. 
Kendisinden Atâ b. Ebû Rebâh, yeğeni Talha b. Yahya (öl. 147/764) ve Muâviye b. İshak b. Talha gibi isimler nakletmiştir. ${ }^{61}$ Okuma-yazması olduğu ve Hz. Âişe'ye kâtiplik yaptığ aktarılmaktadır. Kaynaklarda; sika, âlim, fazilet sahibi şeklinde vasıflanmaktadır. Edebiyat ve şiirde bilgi sahibidir. ${ }^{62}$ Yine bir diğer tabiî, Fâtıma bint el-Münzir b. Zübeyr b. Avvâm'dır. Hişam b. Urve'nin eşi olan Fâtıma; Esmâ bint Ebû Bekr, Ümmü Seleme, babası ve Amre bint Abdurrahman'dan işitmiş, kendisinden ise eşi ve tarihçi İbn İshak (öl. $151 / 768$ ) rivayette bulunmuştur. ${ }^{63}$

Bu isimler arasında Medine'de özellikle Amre bint Abdurrahman Sa'd b. Zürâre ön plana çıkmaktadır. Hadis ve fikıh âlimi olmasının yanı sıra tefsir kaynaklarında da rivayetleri bulunmaktadır. İbn Ebû Dâvûd (öl. 316/929), "Tâbiûn kadınlarının en üstünü Hafsa bint Sîrîn, Amre bint Abdurrahman ve o ikisinden sonra da Ümmü'd-Derdâ'dır." demektedir. ${ }^{64} \mathrm{~Hz}$. Âişe'nin yanında yetişen ve ondan çok şey aktaran Amre bint Abdurrahman bu yönüyle Urve ile kıyaslanmıştır. İbn Sa'd, tabakātında Amre'yi; Urve, Saîd b. Müseyyeb, Süleyman b. Yesâr (öl. 107/725) gibi isimlerle birlikte "Hz. Peygamberin ashâbından sonra Medine'de fetva verenler" başlı̆̆ı altında zikretmektedir. ${ }^{65}$ Ali b. Medînî (öl. 234/848) ise "Amre, Hz. Âişe'nin hadis bilgisine sahip, önemli âlimlerden biridir." ${ }^{66}$ demektedir. Ömer b. Abdülazîz, Medine valisi Ebû Bekr b. Muhammed b. Amr b. Hazm'e (öl. 120/738) "Etrafı iyice araştır, Rasûlullah'ın bir hadisi, bir sünneti veya Amre'ye ait bir beyanını bulursan bana bildir. Çünkü ben, ilmin zayi olmasından endişe ediyorum." demiş; Amre vefat ettiğinde ise "Aramızda Hz. Aişe'nin bilgisine sahip başka biri kalmadı." ${ }^{68}$ demiştir. İttifakla sika kabul edilen Amre, Hz. Âişe haricinde; Ümmü Seleme, sahâbeden Habîbe bint Sehl b. Sa'lebe el-Ensârîyye, Mervân b. el-Hakem (öl. 65/685), Râfî b. Hadîc (öl. 73/692), Abdullah b. Ebû Bekr b. Hazm (öl. 135/752) ve Bey'atürrıdvân'da Hz. Peygamber'e biat edenler arasında yer alan Ümmü Hişâm bint el-

${ }^{61}$ İbn Sa'd, et-Tabakātü'l-kebîr, 10/433; İbn Hibbân, es-Sikāt, 5/288; Hâlid b. Hüseyn, Câmi'u ahbâri'n-nisâ', 401.

62 Mehmet Zihni Efendi, Meşâhiru'n-nisâ’ (İstanbul: Şamil Yayınları, 1982), 2/17. Hakkında geniş bilgi için bk.Fatımatüz Zehra Kamac1, "Tâbiîn Döneminden Seçkin Bir Kadın Portresi Âişe bint Talha”, Marmara Üniversitesi İlahiyat Fakültesi Dergisi 49 (2015), 127-160.

63 İbn Sa'd, et-Tabakātü'l-kebîr, 10/442; İbn Hibbân, Muhammed b. Hibbân b. Ahmed, es-Sikät, 5/301; Mizzî, Tehzîbü'l-Kemâl, 35/265; Kehhâle, A 'lâmü'n-nisâ, 4/146.

${ }^{64}$ Celâlüddin es-Süyûtî, Tedrîbü'r-râvî fi şerhi Takrîbi'n-Nevevî, thk. Ebû Kuteybe Nazar Muhammed el-Fâryâbî (Riyad: Mektebetü'l-Kevser, 1415), 2/710; Hâlid b. Hüseyn, Câmíu ahbâri'n-nisâ', 404. Hafsa bint Sîrîn (öl. 101/719) Muhammed b. Sîrîn'in (öl. 110/709) kardeşi olup Basralı ulemadandır. Ümmü'd-Derdâ ise Dımaşklı'dır. Her ikisi hakkında ilerleyen sayfalarda kısaca bilgi verilmiştir.

65 İbn Sa'd, et-Tabakātü'l-kebîr, 2/332. Amre'nin fikıh bilgisine ve saygınlığına işaret eden bir rivayet şöyledir: "Bir gün Amre, Medine valisi Ebû Bekr b. Muhammed'in, demirden yapılmış bir yüzük çalması sebebiyle Nabatlı birine el kesma cezası vermek için hapsettiğini öğrenir. Bu haber üzerine mevlâsını Ebû Bekr'e göndererek, 'Ey kardeşimin oğlu! Bu Acem’i basit bir şey için alıkoydun. Ona el kesme cezası uygulayacağını öğrendim. Bu ceza ancak dinarın dörtte biri ve daha fazlası için uygulanır.' der. Ebû Bekr, Amre'nin bu ikazı üzerine cezayı uygulamaz ve adamı salar." (Mâlik b. Enes, Muvatta', thk. Muhammed M. el-A'zamî (Ebûzabî, 1465/2004), "Serika", 30).

66 Mizzî, Tehzîbü'l-Kemâl, 35/442.

${ }_{67}$ İbn Sa'd, et-Tabakātü'l-kebîr, 2/333; Ahmed b. Ali Hatîb el-Bağdâdî, Takyîdü'l-iilm, thk. Sa'd Abdülgaffâr Ali (Kahire: Dârü'l-i̇stikāme, 1429/2008), 136.

68 İbn Sa'd, et-Tabakātü'l-kebîr, 2/333; Mehmet Zihni Efendi, Meşâhiru'n-nisâ', 2/82. 
Hârise'den rivayet etmektedir. Süleyman b. Yesâr, Urve b. Zübeyr, İbn Şihâb ez-Zührî, Amr b. Dînâr (öl. 126/744), Ebû Bekr Muhammed b. Amr, Fâtıma bint el-Münzir ve Medine'de kadılık yapan Yahya b. Saîd el-Ensârî (öl. 143/760) gibi çok önemli isimler onun ilminden istifade etmiştir. ${ }^{69}$ Amre'nin Kütüb-i tis' ${ }^{\prime}{ }^{\prime}$ da üç yüz otuz üç hadisi tespit edilmiştir. ${ }^{70}$

Onun tefsirlerde başta fikha ${ }^{71}$ dair olmak üzere sebeb-i nüzûl ${ }^{72}$ nâsih ve'l-mensûh ${ }^{73}$ ve fezâilü'l-Kur'ân ${ }^{74}$ ile ilgili rivayetleri yer almakta ve Amre bu rivayetlerin tamamını Hz. Aişe'den aktarmaktadır. Senedi tam aktaran tefsirlerde kadın tâbiûndan Amre ve Basralı Hafsa bint Sîrîn gibi meşhur olanlarının dahi rivayetleri sınırlı sayıdadır. Sika, âlim, fazilet sahibi, fakih gibi vasıflarla anılan ve Hz. Âişe'nin ilmini en iyi bilen kimse olarak nitelendirilen Amre'nin Câmi'u'l-beyân'da sadece on rivayeti bulunurken ${ }^{75} \mathrm{~Hz}$. Âişe'nin aynı tefsirde üç yüzü aşkın rivayeti yer almaktadır. ${ }^{76}$ Yine Hz. Aişe'nin bilgisine sahip olma bakımından Urve'yle kıyaslanan Amre'nin neredeyse Urve kadar rivayetinin olması beklenirken Urve'nin Hz. Âişe'den aktardığı rivayetler çok daha fazladır. Durumun beklendiği gibi gerçekleşmemesinin muhtemel sebepleri üzerinde durulabilir. Örneğin; meseleye o günkü sosyal yapı ve kadınların toplumdaki görünürlülüğü açısından bakmak mümkündür. Kadınlar, genellikle evlerinde ve ev ortamlarındaki ilim meclislerinde ders yaparken, erkekler toplum içerisinde ve mescitlerdeki ders halkalarında ilimle iştigal etmekteydiler. Dolayısıyla örneğin Urve'den herhangi bir haberi aktaran onlarca kişi bulunurken aynı haberi Amre'den aktaracak kişi sayısı çok daha az olacaktır. Bu da Amre'nin rivayetlerinin belirli ve sınırlı bir grup tarafından aktarılmasına ve sonraki dönemlerde telif edilmiş eserlere daha az yansımasına neden olmuştur, denilebilir. Amre hakkında "Amre bint Abdurrahman ve ârâühe'l-fikhiyye dirâse fikhiyye mukārene" adlı bir makale kaleme alınmıştır. ${ }^{77}$

Son olarak Medine haricinde diğer bölgelerdeki ilim sahibi kadın tabî̂lerden kısaca bahsedebiliriz. Bunlar arasında Mekke'de Safiyye bint Şeybe b. Osman el-Mekkî el-

69 İbn Sa'd, et-Tabakātü'l-kebîr, 2/333, 10/445; İbn Hibbân, es-Sikāt, 5/288; Mizzî, Tehzîbü'l-Kemâl, 35/241-242; Mehmet Zihni Efendi, Meşâhiru'n-nisâ', 2/82; Kehhâle, Alâmü’n-nisâ, 3/356; Bolelli, Kadınların Hadis İlmindeki Yeri, 53; Serpil Başar, Erken Dönemde (Hicrî I. Asır) Kadınların Kur'an Yorumuna Katkıları (İzmir: Dokuz Eylül Üniversitesi Sosyal Bilimler Enstitüsü, Doktora Tezi, 2010), 174.

70 Hatice Tozluk, Amre Bint Abdirrahmân'ın Hayatı ve Rivayetleri (Sakarya: Sakarya Üniversitesi Sosyal Bilimler Enstitüsü, Yüksek Lisans Tezi, 2001), 46.

71 Örneğin bk. Taberî, Câmi'u'l-beyân, 4/225, 506; İbn Ebû Hâtim, Tefsîrü'l-Kur'âni'l-'azîm, 2/411, 3/911; Muhyissünne Hüseyn b. Mes'ûd el-Begavî, Me âlimü't-tenzîl, thk. Muhammed Abdullah en-Nemr - Osman Cum‘a Damîriyye - Süleyman Müslim el-Harş (Riyad: Dâru Tayyibe, 1409), 2/189; İbn Kesîr, Tefsîrü'l-Kur'âni'l'azîm, 1/615.

72 Örneğin bk. Taberî, Câmi'u'l-beyân (thk.Türkî), 17/204, 224; 19/89; Begavî, Me âlimü't-tenzîl, 2/90.

73 Ebü'l-Ferec Abdurrahman İbnü'l-Cevzî, Nevâsihu'l-Kur'ân, thk. Muhammed Eşref Ali (Medine, 1423/2003), $1 / 167$.

74 Örneğin bk. Begavî, Me âlimü't-tenzîl, 8/404; Ebü'l-Fidâ İbn Kesîr, Fezâilü'l-Kur'ân, thk. Ebû İshak el-Huveynî elEserî (Kahire: Mektebetü İbn Teymiyye, 1416), 253.

75 Taberî, Câmitu'l-beyân, 3/543; 4/225, 442, 506, 553; (thk. Türkî) 17/204, 224; 19/89.

76 Tütün, et-Taberînin Câmi'u'l-beyân İsimli Eserinde Hz. Aişe, 23.

77 Esmâ Velid Taha es-Seyyide, "Amre bint Abdurrahman ve ârâühe'l-fikhiyye dirâse fikhiyye mukārene”, Mecelletü'l-'ulûmi'l-İslâmiyye (Irak), 11 (1433). Makaleye ulaşmak için: https://www.iasj.net/iasj?func=fulltext\& aId $=37120$ 
Hacebiyye (öl. 90/709 civarı) ${ }^{78}$ Dımaşk'ta Ümmü'd-Derdâ Hüceyme el-Vassâbiyye esSuğrâ (öl. 81/701) ${ }^{79}$ ve Ömer b. Abdülaziz'in eşi Abdülmelik b. Mervan'ın kızı Fâtıma bint Abdilmelik (öl. 86/705); ${ }^{80}$ Basra'da Muâze el-Adeviyye (öl. 83/702), ${ }^{81}$ Hasan Basrî̀nin annesi, Hz. Ümmü Seleme'nin mevlâsı Hayre, ${ }^{82}$ Hafsa bint Sîrîn ${ }^{83}$ ve Sekîne bint Hüseyin b. Ali (öl. 117/735); ${ }^{84}$ Kûfe'de ise Cesre bint Decâce ${ }^{85}$ gibi isimler sayllabilir.

\section{Sonuç}

Bu çalışmada, sahâbe ve tâbiûn dönemi uleması arasında kadınların tefsir ilmindeki yerleri ele alınmıştır. Sahâbeden Hz. Âişe'nin hem kadın hem erkek sahâbe ve tâbiûn âlimleri üzerinde ciddi bir ağırlığı bulunmakta ve bu durum tefsir kaynaklarına yans1maktadır. Onun yanı sıra Hz. Peygamber'in diğer hanımları Hz. Ümmü Seleme ve Hafsa ile eş-Şifâ bint Abdullah, Ümmü Varaka bint Abdullah b. Hâris, Esmâ bint Yezîd, Esmâ bint Ebû Bekr es-Sıddîk ve Semra bint Nüheyk gibi ilim sahibi kadın sahâbe Kur'ân'1 öğrenme, anlama ve öğretme çabası içerisinde olmuşlardır. Hz. Âişe'nin öğrencisi tâbiî Amre, ilmî yetkinliğiyle dikkat çekmektedir. O, Hz. Âişe'nin ilmine sahip olması bakımindan Urve'yle kıyaslanmıştır. Medine'de fetva verenlerden biri olan Amre'nin Kütüb-i tis'a'da üç yüzden fazla rivayeti kaydedilmiştir. Amre haricinde; Ümmü Külsûm bint Ebû

78 Peygamber hanımları Hz. Ümmü Habîbe (öl. 44/664), Âişe, Hafsa ve Ümmü Seleme'den, Esmâ bint Ebû Bekr'den işitmiş ondan da oğlu Mansûr b. Abdurrahman (öl. 129/747), tâbiî Abdullah b. Safvân b. Ümeyye (öl. 73/692), kārî Humeyd b. Kays el-A'rec (öl. 130/747), Meymûn b. Mihrân (öl. 117/735), Katâde ve Nâfî işitmiştir. Sika kabul edilmiştir. Hicâbe görevi babası Şeybe b. Osman (öl. 59/679) ve onun nesli tarafindan yürütüldüğünden Safiyye de, el-Hacebiyye lakabına sahiptir (ỉbn Sa'd, et-Tabakätül'-kebîr, 10/436; i̇bn Hibbân, es-Sikāt, 4/386; ỉbn Abdilber, el-isttîâb, 917; Mizzî, Tehzîbül'-Kemâl, 35/211; Hâlid b. Hüseyn, Câmi'u ahbâri'nnisâ’', 392). Sahâbe ya da tâbiûndan olduğuyla ilgili farkl görüşler bulunmakla birlikte (ibnü’l-Esîr, Üsdü'lgābe, 7/170; ỉbn Hacer, el-ìsâbe, 8/213; Mizzî, Tehzî̉ü'l-Kemâl, 35/211; Mehmet Zihni Efendi, Meşâhiru'n-nisâ', 1/430). İbn Hibbân, Dârekutnî, Kelâbâzî tarafindan tâbiûn olarak kaydedilmiştir (ỉbn Hibbân, es-Sikāt, 4/386; Alî b. Ömer ed-Dârekutnî, Zikru esmẩi't-tâbi în ve men ba'dehüm mimmen sahhat rivâyetühû 'inde'l-Buhârî ve Müslim, thk. Bûrân ed-Denâvî - Kemal Yûsuf el-Hût (Beyrut, 1406/1985), 1/181). Safedînnin verdiği bilgiye göre 90/709'lu yıllar içerisinde vefat etmiştir (Safedî, el-Vâfi bi'l-vefeyât, 16/190).

79 Tâbiûnun kıraat, hadis ve fikıhta meşhur isimlerindendir. Süyûtî, tefsirde bilgi sahibi olduğunu ifade etmektedir. Eşi Ebü'd-Derdâ'dan çok sayıda rivayeti vardır. Hz. Âişe'den de işitmiştir. Dımaşk mescidinde ders halkası bulunduğundan Mekhûl (öl. 112/730), Zeyd b. Eslem, Ebû Hâzim el-Medenî ve daha birçok sayıda isim ondan rivayet etmiştir. Dimaşk'ta vefat etmiştir (Mehmet Zihni Efendi, Meşâhiru'n-nisầ, 1/98; Hâlid b. Hüseyn, Câmi'u ahbâri'n-nisâ', 396; Ayrıca bk. Ayşe Esra Şahyar, “Ümmü'd-Derdâ el-Vassâbiyye”, Türkiye Diyanet Vakfi İslâm Ansiklopedisi (istanbul: TDV Yayınları, 2012), 427 316).

80 Bolelli, Kadınlarn Hadis ilmindeki Yeri, 52.

81 Hâlid b. Hüseyn, Câmi 'u ahbâri'n-nisâ', 406.

82 Mizzî, Tehzîbül'-Kemâl, 35/166.

83 Ümmü Hüzeyl el-Ensârî el-Basrî olarak künyelenmiştir. Muhammed b. Sîrî'in kardeşidir. Mevlâsı olduğu Enes b. Mâlik'ten (öl. 93/711), Selmân b. Âmir (öl. 35/656 civarı), Ümmü Atıyye el-Ensârî (öl. 70/680) ve Ebü'l-Âliye gibi sahâbe ve tâbiûndan rivayet etmekte ondan da muhaddis tâbiî Âsım el-Ahvel (öl. 142/759), Eyyûb es-Sahtiyânî, İbn Sîrîn, Hâlid el-Hazzâ' (öl. 141/758) rivayet almaktadır. Kıraat, hadis ve fikıhta şöhret kazanmıştır. Muhammed b. Sîrîn, Kur'ân'a dair bir müşkille karşlaştığınızda "Hafsa'ya sorun, o Kur'ân'da bunu nasil okuyor?" demektedir. (ỉbn Sa'd, et-Tabakātü'l-kebîr, 10/448; Hâlid b. Hüseyn, Câmiıu ahbâri'n-nisâ', 403).

84 İbn Hibbân, es-Sikāt, 4/352; Hâlid b. Hüseyn, Câmi'u ahbâri'n-nisầ', 407.

85 Mizzî, Tehzîbül'-Kemâl, 35/143. 
Bekr, Zeyneb bint Ali b. Ebû Tâlib, Hafsa bint Abdurrahman b. Ebû Bekr es-Sıddîk, Safiyye bint Ebû Ubeyd, Aişe bint Talha b. Ubeydullah, Âişe bint Sa'd b. Ebû Vakkās ve Fâtıma bint el-Münzir b. Zübeyr b. Avvâm Medineli tâbiûnun önemli isimleridir. Araştırmanın sonucunda; özellikle tâbiûn döneminde kadınların toplumsal ve ilmî hayattaki görünürlülüklerinin arttığı tespit edilmiştir. Bununla birlikte genellikle evlerinde vakit geçiren ve yine evlerindeki ilim halkalarında Kur'ân, hadis ve fikıh öğrenen kadınların, mescitlerde ilimle iştigal eden erkekler kadar ilmî hayatta ön plana çıktıkları söylenemez. Bu durumun tek istisnası Hz. Aişe'dir. Onun ilminin aktarıcısı olduğu söylenen Amre'nin bile Câmi'u'l-beyân'da sadece on rivayeti vardır. Dolayısıyla onların rivayetleri sonraki dönem kaynaklarına beklenildiği oranda yansımamıştır. Aynı şekilde, tabakāt ve terâcim türü eserlerde haklarında verilen bilgiler son derece sınırlı olup, tefsir ilmindeki konumlarına ise herhangi bir atıf yapılmamıștır. Sayısal olarak onlardan gelen yorum ve rivayetler az olsa da dönemin sosyo-kültürel yapısı da göz önünde bulundurularak, kadınların toplumsal hayatta belli bir yer edindikleri ve eğitim-öğretim faaliyetlerine katıldıkları açık bir şekilde anlaşılmaktadır.

Son olarak; bu çalışma Medineli sahâbî ve tâbiî kadınların tefsir ilmine dair rivayetlerinin değerlendirilmesine bir giriş sayılabilir. Burada bahsedilen şahısların ve rivayetlerinin ayrıntılı tahlil ve tasnifi, ayrıca Medine'nin yanı sıra Mekke, Basra ve Kûfe gibi diğer bölgelerdeki kadınların tefsirle ilgileri de araştırıldığı takdirde ilk devir ilim-kültür mirasında kadınların özellikle tefsir ilmindeki yerlerine dair daha net bir harita çıkarılabilecektir. Buradan hareketle günümüze doğru geldikçe kadınların ilimlerde ve tefsirdeki konumu yeni bir araştırma konusu yapılarak, nihayet çağımızda büyük bir sıçrama yapan kadın ilim insanları ile bu hareketin geldiği nokta üzerine odaklanma imkânı doğacaktır.

\section{Kaynakça}

Ahmed b. Hanbel. Müsned. Thk. Şuayb el-Arnaût - Âdil Mürşid. 50 Cilt. Beyrut: Müessesetürr-Risâle, $1416 / 1995$.

Aydar, Hidayet. Hanım Müfessirler. İstanbul: Ensar Neşriyat, 2015.

Aydar, Hidayet - Atalay, Mehmet. "Female Scholars of Quranic Exegesis in the History of Islam (İslam Tarihinde Kadın Müfessirler)”. Bülent Ecevit Üniversitesi İlahiyat Fakültesi Dergisi 2 (2014), 1-34.

Başar, Serpil. Erken Dönemde (Hicrî I. Asır) Kadınların Kur'an Yorumuna Katkıları. İzmir: Dokuz Eylül Üniversitesi Sosyal Bilimler Enstitüsü, Doktora Tezi, 2010.

Başar, Serpil. “Ümmü Seleme'nin Tefsir Rivayetlerinin Değerlendirilmesi”. Dokuz Eylül Üniversitesi İlahiyat Fakültesi Dergisi 36 (Şubat 2012), 427-448.

Bedr, Abdullah Ebüssuûd. Tefsîru ümmi'l-mü'minîn Aișe. Riyad: Dâru Âlemi'l-kütüb, 1416/1996.

Begavî, Muhyissünne Hüseyn b. Mesû̂d. Meâlimü't-tenzîl. Thk. Muhammed Abdullah en-Nemr Osman Cum'a Damîriyye - Süleyman Müslim el-Harş. 8 Cilt. Riyad: Dâru Tayyibe, 1409.

Belâzürî, Ahmed b. Yahyâ. Fütûhu'l-büldân. Thk. Abdullah Enîs et-Tabbâ‘ - Ömer Enîs et-Tabbâ‘. Beyrut, 1407/1987.

Beyhakī, Ahmed b. Hüseyn. es-Sünenü'l-kübrâ. Thk. Muhammed Abdülkādir Atâ. 11 Cilt. Beyrut: Dârü'l-Kütübi'l-'̇lmiyye, 1424/2003. 
Bolelli, Nusrettin. Kadınların Hadis İlmindeki Yeri. İstanbul: Marmara Üniversitesi İlahiyat Fakültesi Vakfi Yayınları, 1998.

Buhârî, Muhammed b. İsmâil. el-Câmiu's-sahîh. Thk. Muhammed Züheyr b. Nâsır. 9 Cilt. Beyrut: Dâru Tavki'n-Necât, 1422.

Buhârî, Muhammed b. İsmâil. et-Târîhu'l-kebîr. 4 Cilt. Haydarabad: Dâiretü'l-Maârifi'l-Osmâniyye, 1958.

Çalışkan, İsmail. “Tefsir Tarihi Tasavvurunun Yeniden İnşasının Gerekliliği Üzerine”. İslâmiyat Dergisi 8/1 (2005), 11-23.

Çelebi, İlyas. "Rukye". Türkiye Diyanet Vakfi İslâm Ansiklopedisi. 35/ 219-222. İstanbul: TDV Yayınları, 2008.

Dârekutnî, Alî b. Ömer. Zikru esmẩi't-tâbi în ve men ba'dehüm mimmen sahhat rivâyetühû 'inde'l-Buhârî ve Müslim. Thk. Bûrân ed-Denâvî - Kemal Yûsuf el-Hût. 2 Cilt. Beyrut, 1406/1985.

Ebû Dâvûd, es-Sicistânî. Kitâbü's-Sünen. Thk. Şuayb el-Arnaût - Muhammed Kamil Karabelli. 7 Cilt. Dârü'r-Risâleti'l-'Âlemiyye, 1430/2009.

Hâlid b. Hüseyn, Ebû Abdirrahman. Câmi'u ahbâri'n-nisâ' min Siyeru a lâmi'n-nübelâ. Riyad: Mektebetü'r-Rüşd, 1425/2004.

Hatîb el-Bağdâdî, Ahmed b. Ali. Takyîdüll-ílm. Thk. Sa‘d Abdülgaffâr Ali. Kahire: Dârü'l-İstikāme, $1429 / 2008$.

İbn Abdülber, Yûsuf b. Abdullah en-Nemerî. el-İstîâb fi márifeti'l-ashâb. Thk. Âdil Mürşid. Ürdün: Dârü'l-A'lâm, 1423-2002.

İbn Ebû Hâtim, Abdurrahman b. Muhammed. Tefsîrü'l-Kur'âni'l-'azîm müsneden 'an Rasûlillah ve'ssahâbe ve't-tâbi în. Thk. Esad Muhammed Tayyib. 10 Cilt. Riyad: Mektebetü Nizâr Mustafa elBâz, 1417/ 1997.

İbn Hacer, Şihâbüddin Ahmed b. Ali b. Hacer el-Askalânî. Tehzîbü't-Tehzîb. Thk. İbrahim ez-Zeybek Âdil Mürşid. 4 Cilt. Beyrut: Müessesetü’r-Risâle, ts.

İbn Hibbân, Muhammed b. Hibbân b. Ahmed. Kitâbü's-Sikāt. Thk. Muhammed Abdülmuîd Han. Haydarabad: Dâiretü'l-Maârifi'l-Osmaniyye, 1393/1973.

İbn Kesîr, Ebü'l-Fidâ. Fezâilü'l-Kur'ân. Thk. Ebû İshak el-Huveynî el-Eserî. Kahire: Mektebetü İbn Teymiyye, 1416.

İbn Kesîr, Ebü'l-Fidâ. Tefsîrül-Kur'âni'l-'azîm. Thk. Sâmî b. Muhammed es-Selâme. 8 Cilt. Riyad: Dâru Tayyibe, 1420.

İbn Sa'd, Muhammed. et-Tabakātül-kebîr. Thk. Ali Muhammed Ömer. 11 Cilt. Kahire: Mektebetü'lHancî, 1421/2001.

İbnü'l-Cevzî, Ebü'l-Ferec Abdurrahman. Nevâsihu'l-Kur'ân. Thk. Muhammed Eşref Ali. 2 Cilt. Medine, $1423 / 2003$.

İbnü'l-Esîr, İzzeddin Ali b. Muhammed. Üsdü'l-gābe fî márifeti's-sahâbe. Thk. Muhammed Muavvıd Âdil Ahmed Abdülmevcûd. 8 Cilt. Beyrut: Dârü'l-Kütübi'l-'İlmiyye, ts.

Kamacı, Fatımatüz Zehra. "Tâbiîn Döneminden Seçkin Bir Kadın Portresi Âişe bint Talha”. Marmara Üniversitesi İlahiyat Fakültesi Dergisi 49 (2015), 127-160.

Kandemir, M. Yaşar. “Ümmü Seleme”. Türkiye Diyanet Vakfi İslâm Ansiklopedisi. 42/ 328-330. İstanbul: TDV Yayınları, 2012.

Kehhâle, Ömer Rıza. A 'lâmü'n-nisâ' fi'l-âlemeyill-'Arab ve'l-islâm. 5 Cilt. Beyrut: Müessesetü’r-Risâle, ts.

Kurtubî, Muhammed b. Ahmed. el-Câmi' li-ahkâmi'l-Kur'ân ve'l-mübeyyin lemâ tedammenehu mine'ssünneti ve âyi'l-Furkân. Thk. Abdullah b. Abdilmuhsin et-Türkî. 24 Cilt. Beyrut: Müessesetü'rRisâle, 1467/2006.

Mâlik b. Enes. Muvatta'. Thk. Muhammed Mustafa el-A'zamî. 8 Cilt. Ebûzabî, 1465/2004.

Mehmet Zihni Efendi. Meşâhiru'n-nisâ’. 2 Cilt. İstanbul: Şamil Yayınları, 1982. 
Mizzî, Cemâlüddin Ebü'l-Haccâc Yûsuf. Tehzîbü'l-Kemâl fi esmâi'r-ricâl. Thk. Beşşâr Avvâd Ma'rûf. 35 Cilt. Beyrut: Müessesetü’r-Risâle, 1403/1983-1413/1992.

Moğultay b. Kilıç. İkmâlü Tehzîbi'l-Kemâl fî esmâi'r-ricâl. Thk. Âdil b. Muhammed - Üsâme b. İbrâhim. 12 Cilt. Kahire, 1422/2001.

Mukātil b. Süleyman. Tefsîru Mukātil. Thk. Abdullah Mahmûd Şehhâte. 5 Cilt. Beyrut: Müessesetü’tTârîhi'l-'Arabî, 1423/2002.

Müslim, Ebü'l-Hüseyn Müslim b. el-Haccâc. Sahîhu Müslim. Thk. Muhammed Fuâd Abdülbâkī. 4 Cilt. Kahire: Dâru İhyâü'l-Kütübi'l-'Arabiyye, 1412/1991.

Safedî, Salâhüddin Halîl b. Aybek. el-Vâfí bi'l-vefeyât. Thk. Ahmed el-Arnaût - Tezkî Mustafa. 29 Cilt. Beyrut: Dâru İhyâü't-Türâsi'l-Arabî, 1420/2000.

Sa'lebî, Ahmed b. Muhammed. el-Keșf ve'l-beyân 'an tefsîri'l-Kur'ân. Thk. Ebû Muhammed b. Âşûr. 9 Cilt. Beyrut: Dâru İhyâü't-Türâsi'l-Arabî, 1422/2001.

Süyûtî, Celâlüddin. ed-Dürrü'l-mensûr. Thk. Abdullah b. Abdilmuhsin et-Türkî. 17 Cilt. Kahire $1424 / 2003$.

Süyûtî, Celâlüddin. el-ittkān fí 'ulûmi'l-Kur'ân. Thk. Merkezü'd-Dirâseti'l-Kur'âniyye. 7 Cilt. Medine, ts. Süyûtî, Celâlüddin. Tedrîbürr-râvî fi şerhi Takrîbi'n-Nevevî. Thk. Ebû Kuteybe Nazar Muhammed elFâryâbî. 2 Cilt. Riyad: Mektebetü'l-Kevser, 1415.

Şahyar, Ayşe Esra. “Ümmü'd-Derdâ el-Vassâbiyye”. Türkiye Diyanet Vakfi İslâm Ansiklopedisi. 42/ 316317. İstanbul: TDV Yayınları, 2012.

Taberî, Muhammed b. Cerîr. Câmi'u'l-beyân 'an te'vili âyi'l-Kur'ân. Thk. Abdilmuhsin et-Türkî. 26 Cilt. Kahire: Dâru Hicr, 1422/2001.

Taberî, Muhammed b. Cerîr. Câmi'u'l-beyân 'an te'vili âyi'l-Kur'ân. Thk. Mahmûd Muhammed Şâkir Ahmed Muhammed Şâkir. 16 Cilt. Kahire: Mektebetü İbn Teymiyye, ts.

Tozluk, Hatice. Amre Bint Abdirrahmân'in Hayatı ve Rivayetleri. Sakarya: Sakarya Üniversitesi Sosyal Bilimler Enstitüsü, Yüksek Lisans Tezi, 2001.

Tütün, Sevgi. et-Taberînin Câmi'u'l-beyân İsimli Eserinde Hz. Aişe'den Yaplan Rivayetlerin Tesbiti ve Değerlendirilmesi. İzmir: Dokuz Eylül Üniversitesi, Sosyal Bilimler Enstitüsü, Yüksek Lisans Tezi, 1999.

Uyar, Gülgün. “Ümmü Külsûm bint Ebû Bekr”. Türkiye Diyanet Vakfi İslâm Ansiklopedisi. 42/ 324-325. İstanbul: TDV Yayınları, 2012.

Yazır, Elmalılı Muhammed Hamdi. Hak Dini Kur'an Dili. 10 Cilt. İstanbul: Zehraveyn, ts. 